\title{
Estimate private rate of return on technical vocation school and formal school: evidence from Kuwait
}

\author{
Humoud A. Alqattan \\ HIE, PhD, Training Staff, PAAET, Kuwait \\ Email: ha.alqattan@paaet.edu.kw
}

\section{ABSTRACT}

In this paper we asked what can account for the continuing provide technical vocational education in Kuwait? Where the level of development is high and there are high wages government jobs. On the other hand the researcher try to find which of education system track, formal or technical vocation education system is more profitable for individuals in Kuwait. We argue that the answers to these questions are connected through the nature of the earning function and the importance of age effects. This paper will be complemented by an important gap in the development of tools and techniques for analysis part of the education system in the State of Kuwait. This paper is important from three standpoints. First, in order to estimate the effect of education track/path on earnings, the most recent and nationally representative data is used which provides detailed information on the variables. Second, it is an effort to provide an evidence for the comparison between Vocational track/path and Formal track/path in Kuwait education system based on individual earnings. Third, this study provides the policy makers with a helpful technique to monitoring the expenditure on education. To provide policy makers and top management with information needed for comparing technical vocation education with formal education system in Kuwait, this paper offer a new evidence on continue providing technical vocation education in Kuwait by using 2010 Kuwait Civil Service Commission employees database; moreover it is an effort of estimating the private rate of return on formal and technical vocation education system by applying the earning equation. The results suggested keep on offering the technical vocation schools also; find a significant effect on wages depend on the type of education track system. Moreover, the technical vocation education slightly higher returns than the formal education.

\section{INTRODUCTION}

The estimate of the return on investment in education is of great importance for the strategic planning of education and for decision makers in public and private sector (Herrera, 2010; Gustman and Steinmeier, 1981). Education has values for both social (public) and private (individual) economists traditionally use the rate of return on education to understand household decision, also to assist the education policy maker in the planning stage. A positive return encourages the household investment in education because they may desire for return to exceed the returns from alternative investment (Sakellariou, 2003). In this paper we are focusing on the private rate of return on education where the available information relating to education return in Kuwait is currently limited, and according to Psacharopoulos and Patrinos (2004), for developing countries more research on the benefits of schooling is needed. In order to conduct the process of development in Kuwait towards the achievement of its aims, great interest and emphasis should be placed on study of human capital investment accumulation. This study will be complemented by an important gap in the development of tools and techniques for analysis part of the Education system in the State of Kuwait. Furthermore, there is a need for more evidence to study the impact of education on earning.

Based on the aim of this paper we generate these questions:

- What we mean by the rate of return to education?

- How rates of return are actually calculated in practice?

- How rates of return might be useful for policy-makers?

- How can we compare the RORV with RORF?

To tackle the above questions we crate three objectives: 
- To review and examine the past research efforts in the area of the rate of return models in education

- To adopt a model with equation those provides the uniqueness of Kuwait economy and offer estimation for the RORV/RORF in Kuwait.

- To provide policy makers and top management with information needed for comparing technical vocation secondary schools with formal secondary school system in Kuwait.

This paper seeks to expand our knowledge in two ways. First, account the private return benefits of technical vocation and formal education using 2010 individual data for Kuwaitis. Second, the paper sheds light on the impact of age and more experience on technical vocation and formal earning. Kuwait background presented in section 2 ; the modeling approach that we chose to take an earning function; where it is a briefly explain in section 3 and 4 together with a detailed data description which are taken from Kuwait Civil Service Commission; the result of the RORE/RORV are presented in section 5; summery and conclusions presented in section 6 .

\section{METHODOLOGY}

Before we proceed further, let us briefly review the Kuwait education system and labor market this will facilitate a better understanding of the results of this paper. Since, the focus of this paper is on the labor who's graduated from Kuwait high school (formal and technical vocation); this review has been confined to Kuwaitis employees only.

Public education system in the State of Kuwait offers a number of different tracks for the different needs of young people (AL-essa et al., 2007). General education begins with Kindergarten for 4 to 5 year olds and progresses through Primary, Intermediate and Secondary. General education is provided in formal schools, Arabic private schools and schools of Religious education. International private schools offer courses based on the curriculum of their country. Other programs of education are available in schools of special needs education, Such as adult and literacy education. Technical vocation training is offered in PAAET (Public Authority of Applied Education and Training) and Tertiary education is offered in Kuwait University, and the Institutes of Arts and Music studies, the ministry of higher education licensed new private higher education universities such as the American University of Kuwait, Gulf University for science and Technology and Kuwait Maastricht Business School, etc. A map of the secondary education opportunities available to young people in Kuwait is shown in Figure 1.

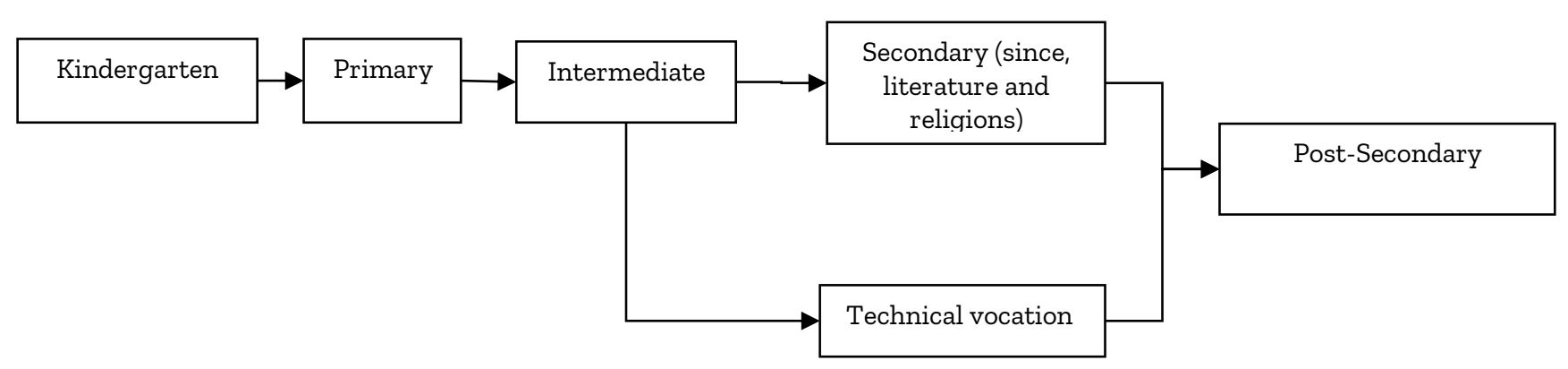

Figure 1. Track/Path of the education opportunities available to young people in Kuwait.

The data for this research is drawn from the Kuwait Civil Service Commission database (Kuwait Civil Service Commission database, 2010.). The Civil Service Commission database comprises 43 ministries and administrations, and covers about 95 percent of all public sector employees. The Civil Service Commission data has 12508 observations of secondary formal school qualification employees and 195 observations of technical vocation school qualification employees. We have used the data from the year 2010 for this research, which is the most recent data available.
In this study the researcher uses only four variables, earnings, type of schooling, ages and years of experience. We select the dependent variable is the log of monthly the basic earnings because it is a significant part of the total earnings as well as to ignore any argument could be made in favor of using just basic salary as the dependent variable rather than total earnings A.l Appendix shows the government pay scales, Three independent variables are used in this study, namely; formal/technical vocation education, years of experience and ages. These have been taken directly from the database without any 
adjustment. The mean, median, maximum, minimum, standard deviation and other statistical variables for the sample data of formal/technical vocation schooling basic earnings, ages and years of experience are reported in Tables 1 and 2 .

\section{Model}

The human capital model of Becker (1962) and Mincer (1974) has been the method used for the study present in this paper. Human capital theory views education as an investment decision. The earning functions have been well applied on individual countries' data, with the semi logarithm specification being very robust in empirical studies. Figure 2 briefly review and explain the earnings model or (Mincerian model).

Mincer (1974) used the first human capital model which was basically focused on the earning function

$$
L n W_{i}=\alpha+\beta_{1} F_{i}+\beta_{2} V_{i}+\gamma_{1} A_{i}+\lambda_{1} E_{i}+\lambda_{2} E_{i}^{2}+\varepsilon_{i} \ldots \ldots \ldots . .(e q .1)
$$

as shown in eq.1

Where:

Ln W: is the natural Log for wage (basic salary in our case).

$\mathrm{F}$ : is the formal schooling.

$\mathrm{V}$ : is the technical vocational schooling.

$\mathrm{E}$ : is the experience years.

$\mathrm{A}$ : is the Age.

: is the random error capture the other variables that have impact on earning but were excluded from model.

We realized here that $\beta_{1}$ is the coefficient for the formal schooling and $\beta_{2}$ is the coefficient for the technical vocation schooling which is the estimated returns.

Subsequent to the above regression and to estimate the proportion of the variance in earnings that is attributable to human capital, we regressed separate regressions of earnings on schooling for various graduation groups get their qualification from Kuwait formal/technical vocation Schools; following the approach of Mincer (1974) and Psacharopoulgos and Layard (1979), Psacharopoulos and Patrinos (2004).

Table 1. Statistics of Kuwaitis employee hold secondary formal schooling qualification

\begin{tabular}{lccc}
\hline Items & Age & Basic Salary & Experience \\
\hline Mean & 38.2 & 249.2 & 12.1 \\
Median & 38 & 216 & 12 \\
Maximum & 73 & 1650 & 53 \\
Minimum & 19 & 110 & 0 \\
Std. Dev. & 7.6 & 105.2 & 8.3 \\
Skewness & 0.1 & 1.9 & 0.4 \\
Kurtosis & 2.7 & 16.1 & 2.3 \\
Jarque-Bera & 79.0065 & 97029.04 & 610.012 \\
Probability & 0 & 0 & 0 \\
Sum & 477642 & 3117104 & 151306 \\
Sum Sq. Dev. & 720721 & $1.39 \mathrm{E}+08$ & 857852.9 \\
Observations & 12508 & 12508 & 12508 \\
\hline
\end{tabular}

Table 2. Statistics of Kuwaitis employee hold technical vocation schooling qualification

\begin{tabular}{lccc}
\hline & Age & Basic Salary & Experience \\
\hline Mean & 32.3 & 262.4 & 10.3 \\
Median & 30 & 240 & 9 \\
Maximum & 59 & 520 & 36 \\
Minimum & 23 & 135 & 0 \\
Std. Dev. & 7.3 & 68.3 & 7.0 \\
Skewness & 1.6 & 1.2 & 1.3 \\
Kurtosis & 5.9 & 4.4 & 5.3 \\
Jarque-Bera & 154.8 & 59.0 & 97.2 \\
Probability & 0 & 0 & 0 \\
Sum & 6289 & 51162 & 1999 \\
Sum Sq. Dev. & 10462.7 & 904509.4 & 9600.7 \\
Observations & 195 & 195 & 195 \\
\hline
\end{tabular}

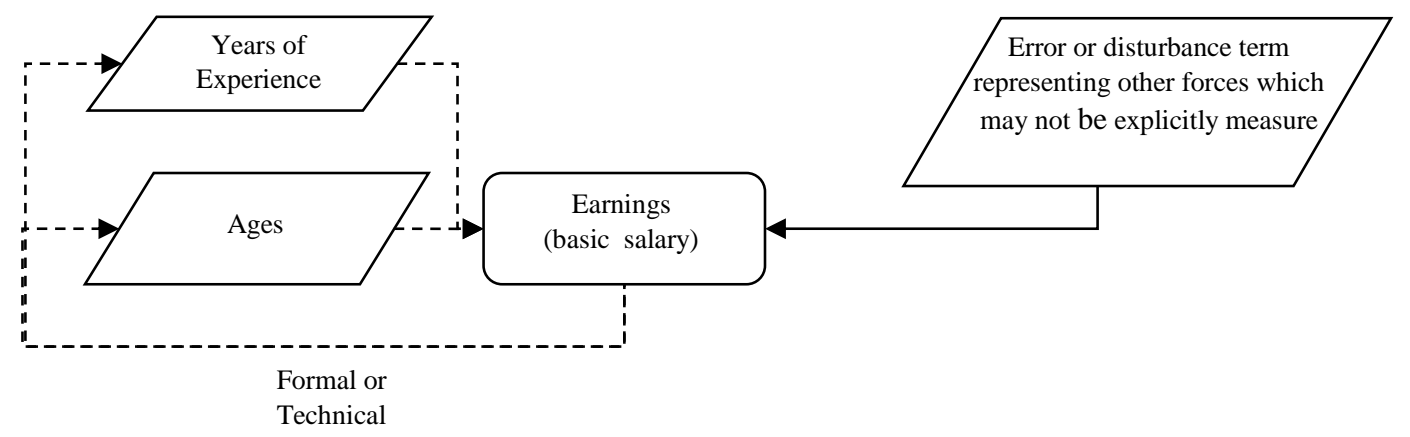

Figure 2. Illustrate of the Earning model (Source: Author's findings) 


\section{RESULTS AND DISCUSSION}

Appling the regression model (eq.1) for the all data using least square method by Eviews package. The resulted estimated regression model is as follows:

\section{Estimation Equation:}

$\mathrm{LOG}(\mathrm{B})=\mathrm{C}(1)^{*} \mathrm{~F}+\mathrm{C}(2)^{*} \mathrm{~V}+\mathrm{C}(3)^{*} \mathrm{~A}+\mathrm{C}(4)^{*} \mathrm{E}+\mathrm{C}(5)^{*} \mathrm{E}^{\wedge} 2$

The average regression for eq.1 estimation reported in table 3 a negative sign for the square term which proofs the impact of over experience. The rate of return to formal schooling 4.7 percent and the rate of return to technical vocation schooling 4.9 percent corresponding $t$-value and $\mathrm{R}^{2}$ are highly significant.

Substituted Coefficients:

$\operatorname{LOG}(B)=4.7^{*} G+4.9^{*} \mathrm{~V}+0.0055^{*} \mathrm{~A}+0.051^{*} \mathrm{E}-0.00045^{*} \mathrm{E}^{\wedge} 2$

Table 4 shows the estimation of formal school regression model for 12508 employees the corresponding $\mathrm{t}$-value and $\mathrm{R}^{2}$ are highly significant.

Substituted Coefficients:

$\mathrm{LOG}(\mathrm{B})=4.7+0.0056^{*} \mathrm{~A}+0.0511^{*} \mathrm{E}-0.00044^{*} \mathrm{E}^{\wedge} 2$ (eq.2)

Table 5 shows the estimation of formal school regression model for 195 employees the corresponding $\mathrm{t}$-value and $\mathrm{R}^{2}$ are highly significant.

Substituted Coefficients:

$\mathrm{LOG}(\mathrm{B})=5.11+0.0023^{*} \mathrm{~A}+0.041^{*} \mathrm{E}-0.00043^{*} \mathrm{E}^{\wedge} 2$ (eq.3)

Table 3. The average regression model estimation

\begin{tabular}{lcccc}
\hline Variable & Coefficient & Std. Error & t-Statistic & Prob. \\
\hline G & 4.7 & 0.0085 & 551.16 & 0.0000 \\
\hline V & 4.9 & 0.013 & 369.60 & 0.0000 \\
\hline A & 0.0055 & 0.00025 & 21.81 & 0.0000 \\
\hline E & 0.051 & 0.00056 & 91.86 & 0.0000 \\
\hline$E^{\wedge} 2$ & -0.000448 & $1.89 E-05$ & -23.77 & 0.0000 \\
\hline R-squared & 0.84 & Mean dependent var & 5.44 \\
\hline Adjusted R-squared & 0.84 & S.D. dependent var & 0.38 \\
\hline S.E. of regression & 0.155 & Akaike info criterion & -0.89 \\
\hline Sum squared resid & 303.85 & Schwarz criterion & -0.89 \\
\hline Log likelihood & 5685.73 & Hannan-Quinn criter. & -0.89 \\
\hline Durbin-Watson stat & 1.44 & \multicolumn{3}{l}{} \\
\hline Source: Author's & & &
\end{tabular}

Table 4. The formal school regression model estimation

\begin{tabular}{lcccc}
\hline Variable & Coefficient & Std. Error & t-Statistic & Prob. \\
\hline C & 4.7 & 0.0086 & 547.43 & 0.0000 \\
\hline $\mathrm{A}$ & 0.0056 & 0.00025 & 22.15 & 0.0000 \\
\hline $\mathrm{E}$ & 0.051 & 0.00056 & 90.966 & 0.0000 \\
\hline $\mathrm{E}^{\wedge} 2$ & -0.00045 & $1.91 \mathrm{E}-05$ & -23.35 & 0.0000 \\
\hline R-squared & 0.84 & Mean dependent var & 5.44 \\
\hline $\begin{array}{l}\text { Adjusted R- } \\
\text { squared }\end{array}$ & 0.84 & S.D. dependent var & 0.39 \\
\hline S.E. of regression & 0.155 & Akaike info criterion & -0.89 \\
\hline Sum squared resid & 300.083 & Schwarz criterion & -0.89 \\
\hline Log likelihood & 5579.75 & Hannan-Quinn criter. & -0.89 \\
\hline F-statistic & 21721.73 & Durbin-Watson stat & 1.44 \\
\hline Prob (F-statistic) & 0.000000 & & \\
\hline Source: Author's & & &
\end{tabular}

Table 5. The technical vocation school regression model estimation

\begin{tabular}{lcccc}
\hline Variable & Coefficient & Std. Error & t-Statistic & Prob. \\
\hline $\mathrm{C}$ & 5.11 & 0.07 & 76.31 & 0.0000 \\
\hline $\mathrm{A}$ & 0.0023 & 0.003 & 0.84 & 0.40 \\
\hline $\mathrm{E}$ & 0.041 & 0.004 & 11.44 & 0.0000 \\
\hline $\mathrm{E}^{\wedge} 2$ & -0.00043 & 0.000102 & -4.26 & 0.0000 \\
\hline R-squared & 0.805 & Mean dependent var & 5.54 \\
\hline Adjusted R-squared & 0.801693 & S.D. dependent var & 0.244 \\
\hline S.E. of regression & 0.11 & Akaike info criterion & -1.59 \\
\hline Sum squared resid & 2.23 & Schwarz criterion & -1.52 \\
\hline Log likelihood & 159.17 & Hannan-Quinn criter. & -1.56 \\
\hline F-statistic & 262.43 & Durbin-Watson stat & 1.91 \\
\hline Prob (F-statistic) & 0.000000 & & \\
\hline Source: Author's & & &
\end{tabular}

Based on the above tables we can conclude that:

- The rate of return on formal secondary schooling 4.7 percent.

- The rate of return on technical vocation secondary schooling 4.9 percent; corresponding

- A negative sign for the square term which proofs the impact of over experience.

- The Age of individual is not significantly affecting the wages learnings.

${ }^{*} t$-value and $R^{2}$ are highly significant.

These empirical findings raise several important questions. The results indicate that significant rates of return on both education systems in Kuwait are positive and technical vocation slightly higher than formal, In addition, coefficient of Age insignificant. Also, there are several possible explanations for this finding. First, the government pay scales are determined largely on the basis of the number of 
years of schooling with little consideration to the area of specialization. Second, the average education of women in Kuwait is higher than that of men.

\section{CONCLUSION}

Education is one of the many investment decisions motivated by the fact that the investment yields a choice that one would not otherwise have. Part of the return to the investment is to be found in the set of options that emerges. For instance, when an individual decides upon the education track to be attained, it is believed that such academic qualification will lead to a better-paid job. That qualification will also extend the number of options in other matters, as well, such as the sector and/or specific firm where the individual will be employed. Part of the individual's return to education will thus be the return to subsequent choices that are available only after qualification is obtained.

Based on the findings of this paper the researcher can conclude that, Kuwait vocational education system at the secondary level has successfully addressed the needs of the market/industry, better match between skills acquired in school and the industry will expected to accelerate the school-towork transition, better match of vocational skills and industry needs would increase the expectation that the labor market will reward vocational skills better than general education (other factors remaining unchanged) and the important observations is that the rate of return on technical vocation education slightly higher than the rate of return on formal education, however this finding is inconsistent with the findings of many other researchers (Gustman and Steinmeier, 1981, Meyer and Wise, 1982, Neuman and Ziderman, 2003), but it is counterpart with other such as Bennell and Segerstrom (1998) and Moenjak and Worswick (2003) for Thailand.

In addition, even though the coefficient of age in eq. 3 is insignificant there are possible explanations for this finding. First, the age affects the individual choice in selecting the technical vocation school. Second, the gap in ages between the technical vocation school students. Third, the government pay scales are little consideration to the area of specialization.

The main objectives of this paper were to present estimates of the returns for the two track of secondary level education system in Kuwait and demonstrate the impact of more experience and ages on earning. The use of the Mincer equation in its simpler form seems to give an approximate value for the total return on education.
There are number of future research direction could be studied for instance, the influence of education in the choice of sectors and other decisions taken after school should be taken into account when one studies the full benefits brought by education to an individual, the effect of selecting secondary level track on higher education and the influences of technical vocation education on labor market.

\section{Acknowledgements}

The author grateful to the editor of this conference, and would like to thank Dr. Bachir Talibi for this helpful comments and assistance. The author is responsible for remaining errors.

\section{REFERENCES}

Gustman, A. L., \& Steinmeier, T. L. (1982). The relation between vocational training in high school and economic outcomes. NBER Working Papers 0642, National Bureau of Economic Research, Inc. ILR Review, 36(1), 73-87. Google Scholar, https://doi.org/10.1177/001979398203600105

AL-essa, A.A., Ammar, S., AL-baloul, D., AL-Qallaf, W., Alaa, H., AL-Jumah, N., Bahbahani, A. and AL-Hussainan, E. (2007) Education Indicators in the State of Kuwait, Kuwait

Bennell, P., \& Segerstrom, J. (1998). Vocational education and training in developing countries: Has the World Bank got it right?. International Journal of Educational Development, 18(4), 271-287. https://doi.org/10.1016/S0738-0593(98)00021-2 , Google $\underline{\text { Scholar }}$

Mincer, J. (1974). Education, experience, and earnings. J. Mincer.-NY. Google Scholar

Becker, G. S. (1962). Investment in human capital: A theoretical analysis. Journal of political economy, 70(5, Part 2), 9-49. Direct Link, Google Scholar

Kuwait Civil Service Commission database (2010). Kuwait.

Alqattan, H., Stergioulas, L., \& Al-Zayer, J. (2012, August). The Returns to Education Based on Level of Education: Case of Kuwait. In European Business Research Conference Proceedings. Google Scholar, https://ssrn.com/abstract $=2130636$

Herrera, L. (2010). MENA Development Report. The Road Not Traveled. Education Reform in the Middle East and North Africa. Google Scholar, JSTOR

Meyer, R. H., \& Wise, D. A. (1983). The effects of the minimum wage on the employment and earnings of youth. Journal of Labor Economics, 1(1), 66-100. Link , Google Scholar

Moenjak, T., \& Worswick, C. (2003). Vocational education in Thailand: a study of choice and returns. Economics of 
Education Review, 22(1), 99-107. Google Scholar, https://doi.org/10.1016/S0272-7757(01)00059-0

Neuman, S., \& Ziderman, A. (2003). Can vocational education improve the wages of minorities and disadvantaged groups?: The case of Israel. Economics of education review, 22(4), 421-432. Google Scholar, https://doi.org/10.1016/S0272-7757(02)00094-8

Psacharopoulos, G., \& Layard, R. (1979). Human capital and earnings: British evidence and a critique. The Review of Economic Studies, 46(3), 485-503. JSTOR, Google $\underline{\text { Scholar }}$
Psacharopoulos, G., \& Patrinos, H. A. (2004). Human capital and rates of return. International Handbook on the Economics of Education, 1-57. https://doi.org/10.4337/9781845421694.00006, Google Scholar

Sakellariou, C. (2003). Rates of return to investments in formal and technical/vocational education in Singapore. Education Economics, 11(1), 73-87. Google Scholar, https://doi.org/10.1080/09645290210127525 
Table of grades, salaries and social allowance categories (Kuwaiti / non-Kuwaiti)

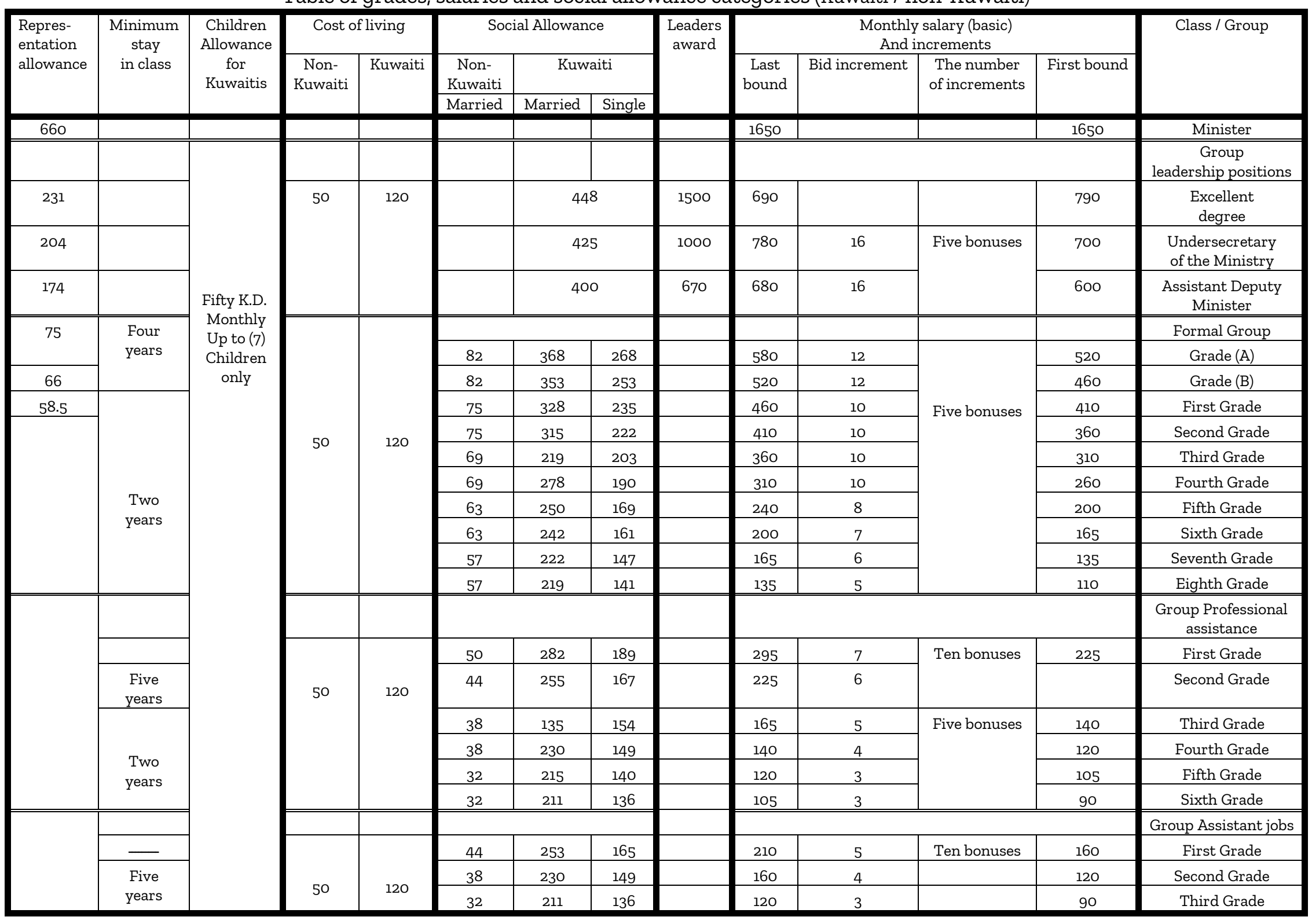


- Note: In addition to the above gives the employee the Kuwaiti increase in salary (50 dk) per month with effect from $1 / 7 / 2005$ the disposal of an item type bonuses, allowances, bonuses and other allowances in implementation of the Council of Ministers Decision No. (698/2005) on 2 / 7/2005, provided that it has not granted any allowance or increase the cadre during the five years preceding the issuance of the decision (i.e. from 01.07.2000 to 07.01.2005) and by grants from increasing the transfer of this amount gives the difference.

- According to Law No. (27/2008) and the Council of Ministers Resolution No. (606 for the year 2008) and to mainstream the SAI No. (49/2008) gives the employee the Kuwaiti reward financial support terms that are net salary (1000 d. k) and maximum (50 d. k) per month with effect from 08.28.2008. 